\title{
A Year in the COVID-19 Epidemic: Cuba and Uruguay in the Latin American Context
}

\author{
Luis Carlos Silva-Ayçaguer and Jacqueline Ponzo-Gómez
}

Translated from the Spanish and reprinted with permission from the Revista Cubana de Higiene y Epidemiología, Vol 59, 2021, ID 1063. Original available at: http://www.revepidemiologia.s/d.cu/index.php/hie/article/view/1063

\begin{abstract}
INTRODUCTION One year after WHO declared COVID-19 a pandemic, we found it useful to carry out a diagnosis of the situation in Latin America.
\end{abstract}

OBJECTIVES Examine the prevailing epidemiological panorama in mid-March 2021 in 16 countries in Latin America and the performance, over time, in the two countries with the best responses to their respective epidemics.

METHODS Using morbidity and mortality data, we compared the relative performance of each country under review and identified the two countries with the most successful responses to the pandemic. We used five indicators to analyze the course of each country's performance during the pandemic throughout 2020: prevalence of active cases per million population; cumulative incidence rate in 7 days per 100,000 population; positivity rate over a 7-day period; percentage of recovered patients and crude mortality rate per $1,000,000$ population.

RESULTS According to the performance indicators, Cuba was ranked highest, followed by Uruguay. Although figures remained within acceptable margins, both nations experienced notable setbacks in the first weeks of 2021, especially sharp in Uruguay.

CONCLUSIONS Any characterization of the situation is condemned to be short-lived due to the emergence of mutational variants; however, this analysis identified favorable sociodemographic characteristics in both nations, and in their health systems, which may offer possible explanations for the results we obtained.

KEYWORDS COVID-19, infodemic, Latin America, Uruguay, Cuba

\section{INTRODUCTION}

At the start of 2021, the world continues to experience dramatic effects associated with the emerging disease COVID-19 caused by the novel coronavirus SARS-CoV-2. Much was learned in 2020 regarding the virus's behavior, both in the body and society. Today there are well-defined, specific protocols for patient treatment[1,2] which has made it possible to mitigate deaths attributable to the virus, and dozens of vaccine candidates are in experimental stages, in the hope that they may prove effective and safe in preventing infection.

Personal hygiene-particularly handwashing-physical distancing, avoiding crowds in closed spaces, and the use of masks, were quickly identified as the most effective means of avoiding contagion.[3] Collectively, other measures have been implemented, including border closures and isolation. These are preventive measures that are not without controversy, but which became almost universally accepted since the beginning of the 20th century, as can be seen in historical studies.[4] This is also attested to by an article published in the US newspaper Douglas Island News more than a century ago,[5] on the occasion of the misnamed 'Spanish flu.'

Currently the pandemic is exhibiting aggressive dynamics and, according to the Pan American Health Organization (PAHO), we are far from reaching an endemic stage.[6] Since May 2020, the World Health Organization (WHO) had stated that endemicity was a possible outcome of the current pandemic. More recently, WHO authorities have reiterated that even given the existence of one or more effective and safe vaccines, it is possible that COVID-19 will remain an endemic disease in the world, both due its great diffusion worldwide, and because of the potential it has to survive in an animal reservoir.[7]

New knowledge occurs at high speeds during emergencies and results in operational challenges for all affected countries. The wealth of data attempting to characterize the pandemic is remarkable. Identifying those data that are truly valuable, condensing them, and, above all, translating them into possibly useful community actions for decision-makers and citizens, is a continuous and pressing need.

EndCoronavirus is a coalition of scientists that came together in response to the pandemic.[8] Based at the New England Complex Systems Institute (NECSI), it manages an open platform where it shares analyses and data from all over the world. Analogous instruments have been created, among others, by the John Hopkins University Resource Center,[9] the Brown School of Public Health[10] and the World Health Organization.[11]

A tour of these sites allows a panoramic look at COVID-19 data at the global level and at differing patterns at the national level. The pandemic has expanded over months with little or no containment in some countries (such as Brazil, the United States and the United Kingdom) and other countries that had initially achieved promising favorable scenarios experienced late and frequent outbreaks (as was the case with Germany, Malaysia and Belarus). Other countries currently show signs of effective control (including Iceland, New Zealand and Singapore).

Informational spaces of this type, however, usually offer temporal characterizations related to disease distribution, without delving deeply into the other central aspect of epidemiology: determinations of health or disease.

In every epidemic, what could have been thought 'merely medical' attains deeply social connotations. In this context, epidemiological 
science, especially critical epidemiology, unravels not only the distribution of the disease but also its determinative processes, which recognize the importance of the social framework. In journalistic or digital media, not only is the social analysis of the problem often hijacked, but it is occasionally trivialized or contaminated with sensationalism, misrepresentation and political bias.[12]

In this framework, epidemiology is urged to make contributions based on its most important mandates: identification of spatial and temporal patterns of the pandemic, on the one hand, and on the other, its uncertain and changing evolution. At the same time, it must deepen critical examination of the results attained as a function of response actions deployed in different contexts.

Now, after 12 months of struggling to contain the epidemic since its arrival in Latin America, it is time to characterize the prevailing situation in the region, analyze the course of the epidemic through to the current situation, and evaluate how the epidemic has been handled by the media. We know that any characterization is condemned to be ephemeral or provisional because it concerns an ever-changing and constantly developing process. Howevereven with necessarily provisional results-this analysis can help us understand the determinative processes in this new phenomenon full of uncertainty. Added to this is the methodological value derived from the exercise consisting in illustrating some avenues of analysis that transcend the mere phenomenological exposition during a given period of the epidemic process. For the above reasons, we propose to examine the prevailing epidemiological panorama in mid-March 2021 in 16 countries of the region and the performance, over time, of the two countries that achieved the best results.

\section{METHODS}

This is a descriptive study where an examination of the prevailing situation in most Latin American countries was carried out one year after the outbreak of the epidemic in the region. We examined data corresponding to 16 Latin American countries. Some nations were excluded due to the dubious reliability of the data they provide. This was attributed to the relative weakness of their statistical systems (the case of Haiti);[13] to the fact that the official data fail to conform to standards dictated by international organizations (the case of Nicaragua); $[14,15]$ or to the fact that the validity of the reported figures has aroused suspicions and been called into question, as were the cases of Venezuela[16] and El Salvador.[17,18] Although there are numerous indicators that can be used in this endeavor-related to prevention, health services, community participation and surveillance, among others-we have concentrated on morbidity and mortality due to their socioepidemiological and public health importance.

For this initial analysis, the respective classic descriptive epidemiology indicators were used: mortality rate $\left(R_{1}\right)$, and cumulative incidence rate of detected cases $\left(R_{2}\right)$, both per million population. Both the definitions of the rates and the data used are those that appear at https://ourworldindata.org/coronavirus

Let us call $R_{i j}$ the $i^{\text {th }}$ rate (i: 1,2$)$ corresponding to the $j^{\text {th }}$ country ( $\mathrm{j}$ : $1, \cdots, 16), \min \left(R_{i}\right)$ is the lowest value among the $R_{i}$ rates of the 16 countries considered and $\max \left(R_{i j}\right)$ is the highest. The relative risk of dying and becoming ill was computed for each country in relation to the one that exhibited the lowest rate ${ }^{\mathrm{A}}$. That is, it was computed as:

$$
R R_{i j}=\frac{R_{i j}}{\min \left(R_{i}\right)}
$$

To establish an order among the countries regarding the impact of the epidemic based on two indicators that concern conceptually different dimensions, a single impact index was constructed. First, a relative impact index was calculated for each of the rates and for each country, which we will call the "relative rate" (RRate $\left.{ }_{\mathrm{ij}}\right)$ :

$$
\text { RRate }_{i j}=\frac{\max \left(R_{i}\right)-R_{i j}}{\max \left(R_{i}\right)-\min \left(R_{i}\right)}
$$

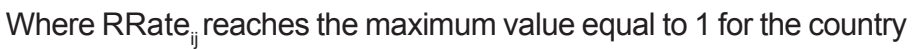
with the lowest value of $R_{i}$ and the minimum value equal to 0 for the country with the highest $R_{i}$. Finally, the index WMRR is computed for each country through a weighted average of the two relative rates; the formula gives more weight to mortality than to morbidity (weights 0.6 and 0.4, respectively): WMRRate W $_{j}(0.6)\left(\right.$ RRate $\left._{1 \mathrm{j}}\right)+(0.4)\left(\right.$ RRate $\left._{2 \mathrm{j}}\right)$.

Second, based on the results obtained above, the two countries with the best indicators to date in the analysis (concluded on March 10, 2021) were Cuba and Uruguay. Their results were examined in detail throughout the period since the initial outbreak of the epidemic in the region. Emphasis was placed on daily performance of the following five indicators.

1. Prevalence rate of active cases (PRAC) per million population

PRAC $=\frac{\text { Number of active cases present on a single day }}{\text { Population size }} 10^{6}$

where active cases in a day is the total number of persons diagnosed up until that day, minus the total number of deceased and recovered individuals.

\section{Average cumulative incidence rate $(\mathrm{ACIR} 7)$ in 7 days per} 100,000 population

This is the calculation, for each day, of the average number of new cases detected during the previous week, also known as the Harvard P7 index.[19]

$$
A C I R 7=\frac{\text { Average number of cases in the past seven days }}{\text { Population size }} 10^{5}
$$

3. Positivity rate for each day and the preceding six days (PR7)

Occasionally absolute thresholds are used to monitor the course of the epidemic. One of them, promoted by $\mathrm{WHO},[20]$ is the so-called 'positivity rate' in a period determined by two moments $\mathrm{t}_{1}, \mathrm{t}_{2}$, defined as:

$P R\left(r_{1} ; r_{2}\right)=\frac{\text { Number of positive cases in period }\left(r_{1} ; r_{2}\right)}{\text { Number of diagnostic exams performed during period }\left(r_{1} ; r_{2}\right)} 100 \%$

We also calculated the PR corresponding to seven consecutive days. That is, for each day, the numerator is the sum of cases 
detected that day $\left(r_{1}\right)$ and the previous six days $\left(r_{2}=r_{1}-6\right)$, where the denominator is the sum of the tests carried out in those seven days. To underscore that this is the chosen period, we will call it PR7 from now on.

4. Percentage of patients who recovered (RP) to date $R P=\frac{\text { Number of recovered infected cases }}{\text { Numbers of diagnosed infected cases }} 100 \%$

Recovery criteria is not the same in all countries. In particular, this is the case in Cuba and Uruguay: while in Cuba a negative RT-PCR (real-time polymerase chain reaction) test has always been considered a recovery criterion, Uruguay, since October 2020, uses clinical and evolutionary criteria to grant hospital discharge without requiring a negative RT-PCR test.

5. Crude mortality rate $(\mathrm{CMR})$ per million population

$$
C M R=\frac{\text { Number of deaths to date }}{\text { Population size }} 10^{6}
$$

We used the daily official reports provided by the National Emergency System of Uruguay[21,22] and by the Ministry of Public Health of Cuba[23] for all calculations. The article is therefore based entirely on secondary data from publicly accessible sites. Consequently, there are no potential ethical problems pertaining to data collection or analysis.

\section{RESULTS}

The situation in Latin America The table contains relevant data on COVID-19 mortality and morbidity in the 16 Latin American countries included in the study.

Cuba is used as a reference for the purposes of calculating relative risks (columns 3 and 6 ). This is due to the fact that it occupies the best position for both indicators in mid-March 2021. In terms of mortality, Uruguay follows, although with an appreciable difference: a crude mortality rate 6.2 times higher, which is still appreciably distant from the rest. In terms of morbidity, after Cuba, there are several countries with similar rates.

For the weighted average of relative rates (column 7), which condenses the impact of the epidemic in terms of mortality and morbidity, Cuba and Uruguay occupy the best places (in that order).

The epidemic's evolution in Cuba and Uruguay The comparison of Cuba and Uruguay is useful because they are the two countries with the best results, as well as because of their similarity in some areas that are either directly or indirectly related to the epidemic.

They are relatively isolated nations-Uruguay due to its southern latitude and Cuba due to its insularity —and they are relatively small countries that have large neighbors (Brazil and the United States, respectively) with very high levels of SARS-CoV-2 dissemination. Both have quality health and primary care systems. Cuba and Uruguay have the oldest populations in the region: the median ages are the highest (43.1 and 35.6 years, respectively) and they also have the highest percentages of people over 70 years $(9.7 \%$ and $10.4 \%$ ). Their populations have a high educational level in the context of Latin America; exhibit the lowest infant mortality rates in the region (4.7 deaths per thousand live births in Cuba and 7.0 in Uruguay); and rate very highly on the UN Development Program's Human Development Index (HDI) in the regional context (the value for Uruguay is 0.817 and Cuba's is 0.783 , according to the 2019 Report).[24]

They are also relative equals regarding the equitable distribution of income as measured by the Gini Coefficient (GC). In Uruguay it is 0.42. In Cuba, although the last known measurement is from 1999 (GC 0.41), it is estimated that in successive years it has remained at the same level.[25] With these values, Cuba and Uruguay occupy the best places in Latin America and the Caribbean for this indicator.

One notable difference lies in the political system. Cuba is a socialist country, while Uruguay is governed by a coalition of the right and center-right, although it is the successor to a leftist government that ruled for 15 years and ended just before the start of the pandemic, on March 1, 2020.

Another similarity, now in reference to the epidemiology of COVID-19, is the sustained growth that both countries have presented in the number of active cases throughout the past quarter, after several months of very favorable evolution, until they reached what can be considered the worst moments of the epidemic in both countries.

The successes of both Uruguay and Cuba in the first months of their respective epidemics have been progressively and seriously compromised during 2021. In the first months of this year, the number of active cases in the same day skyrocketed and broke records in both nations: for Cuba, this number rose to 5800 (February 1) while for Uruguay it reached 9261 (March 11). In just the first 10 weeks, Uruguay accumulated $74 \%$ of all deaths and $72 \%$ of all diagnosed cases. For Cuba, these data are similarly disturbing ( $61 \%$ of the deaths and $82 \%$ of all cases).

Figure 1 shows that shortly after the beginning of 2021, both countries (analyzed separately), show an epidemic trend that could well be described as 'alarming'. The two curves reflected there record the epidemic's evolving dynamics in the two countries. A critique has been raised that these judgments are established based on absolute numbers and not on rates;[26] for example, statements like the "epicenter of the epidemic" is located in a certain country or region, which are deemed questionable because they are based on numbers of this type (accumulated cases or registered deaths) instead of using the corresponding rates. Consequently, in order to establish adequate comparisons between countries, we calculated the rate of active cases per million population. Using the aforementioned rates, it can be seen that the situation in Uruguay on March 10, 2021 was 6 times more critical than that of Cuba (rates of 2505.1 and 410.8 respectively).

Note (Fig. 1) that the growth of Cuba's PRAC curve becomes much less pronounced when placed in the context of both countries.

The curves show a marked similarity during the first eight months of the epidemic, including the absence of a 'first wave' indicating a high incidence of new cases, which affected other countries in the region in 2020, but not Cuba or Uruguay. However, that 
marked similarity disappears during the last semester; a pattern repeated when examining other selected indicators. And this trend allows us to glimpse what may be galloping growth over the next few weeks for Uruguay.

In relation to the ACIR7 Index, which measures the immediately prior situations experienced every day in terms of new cases, the similarity between the two countries is notable until mid-November, when the Uruguayan rates begin to take off (Fig. 2).

It should be noted that the fewer tests carried out, the fewer cases will be detected. Consequently, a country with a lower testing rate would 'benefit' when countries are compared using indicators that increase as said rate increases, as occurs with the PRAC and the ACIR7. This problem, however, does not affect our analysis, as the testing rates performed per 1000 population in Cuba and Uruguay in the period in which the differences were most marked are quite similar: 100.6 and 135.7, respectively, throughout 2021.

Another indicator analyzed is the positivity rate in the diagnostic tests performed for seven successive days (TP7). Until mid-November, this rate fluctuates below $2 \%$ for both countries; after which the index increases in both countries. However, while in Cuba the PR7 remains below $5 \%$, the threshold considered the maximum acceptable by $\mathrm{WHO},[27]$ in Uruguay it fluctuates at around $10 \%$ (Fig. 3).

The recovery rates of previously diagnosed patients have been high and remained similar throughout the entire period (Fig. 4). Cuba has exhibited better results in this area for much of the period, but since mid-October, the percentages have tended to equalize and remain at very high levels in both countries.

Mortality is, in our opinion, the most important of all indicators for obvious reasons. Once again, after exhibiting remarkable similarity until the middle of 2020 , the mortality rate in Uruguay begins to take off very notably (Fig. 5), until it reaches the current situation-as of March 12, 2021: Cuba has experienced 361 deaths and 688. Uruguay's population is one third that of Cuba's $(3,461,734$ vs. $11,333,483)$, resulting in a mortality rate
Figure 1: Prevalence rates of active COVID-19 cases per million population, Cuba and Uruguay; March 11, 2020-March 10, 2021

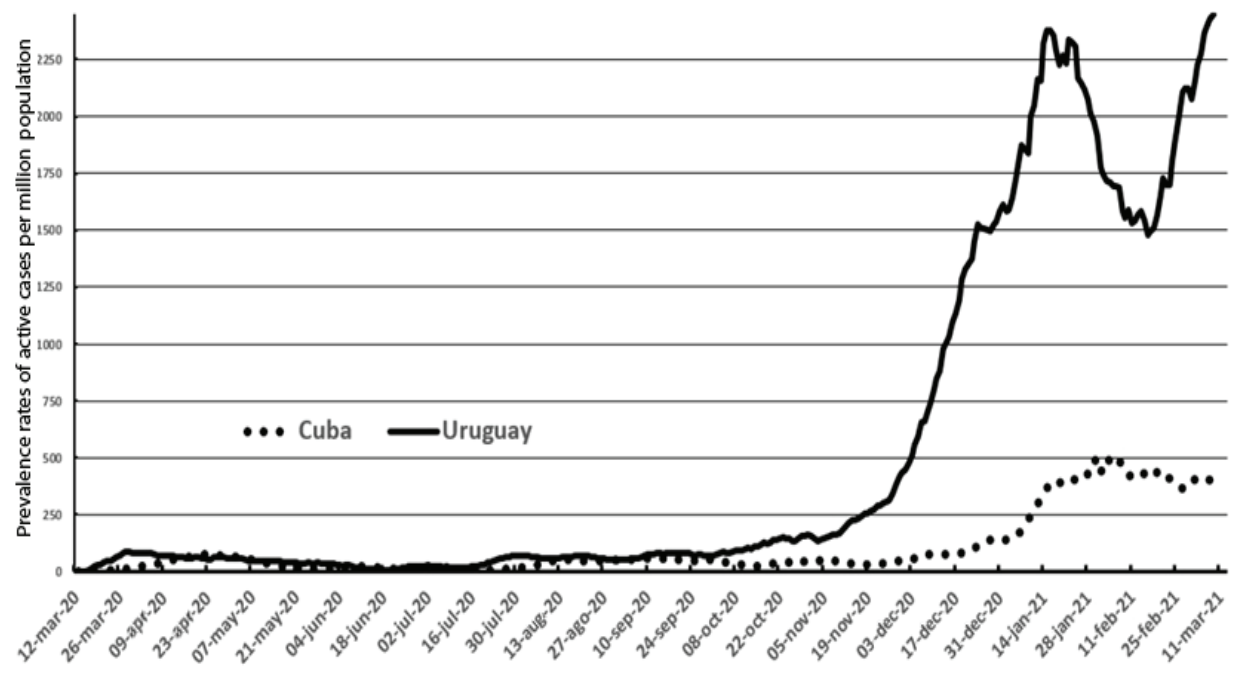

Figure 2: Moving average of accumulated COVID-19 cases in last 7 days per 100,000 population, Cuba and Uruguay; March 11, 2020-March 10, 2021

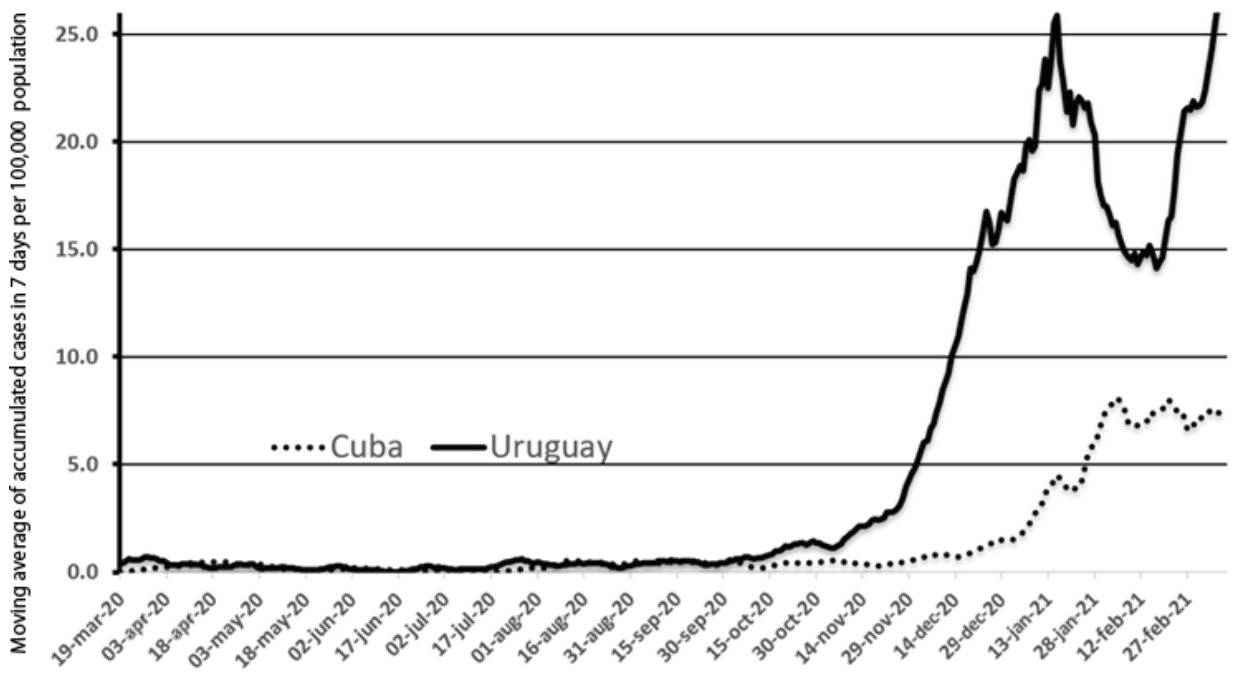

Figure 3: Seven-day moving COVID-19 positivity rate, Cuba and Uruguay; March 11, 2020 March 10, 2021

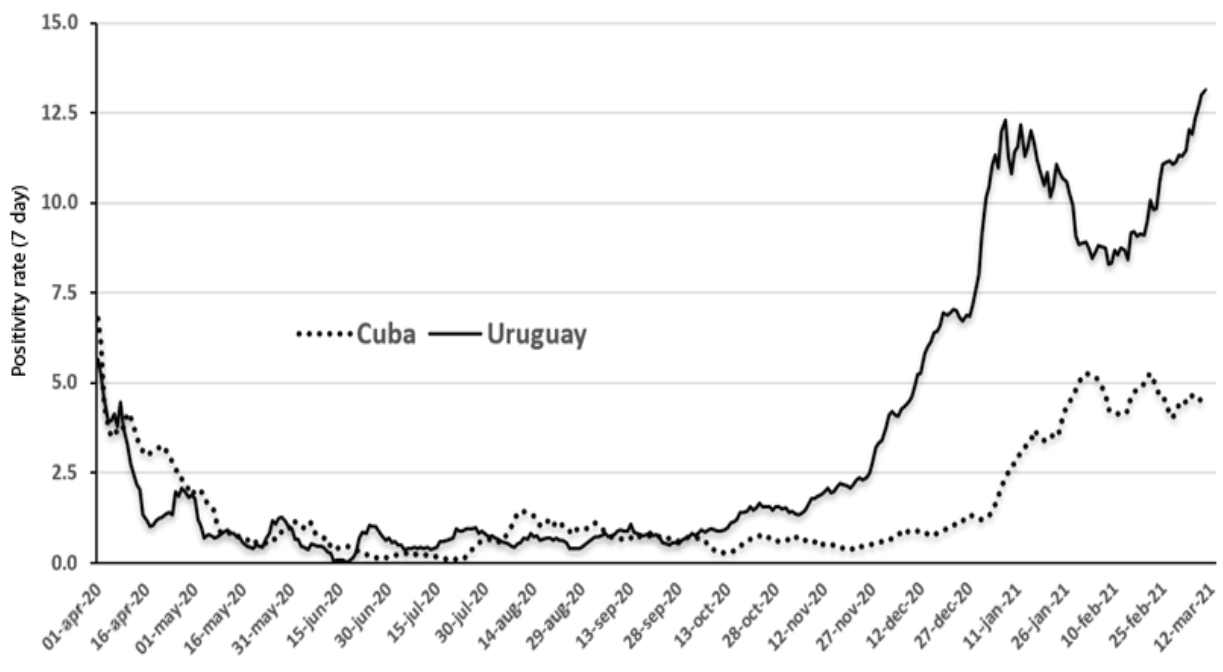


Figure 4: Percentage of people diagnosed with COVID-19 who have since recovered, Cuba and Uruguay; May 1, 2020-March 10, 2021

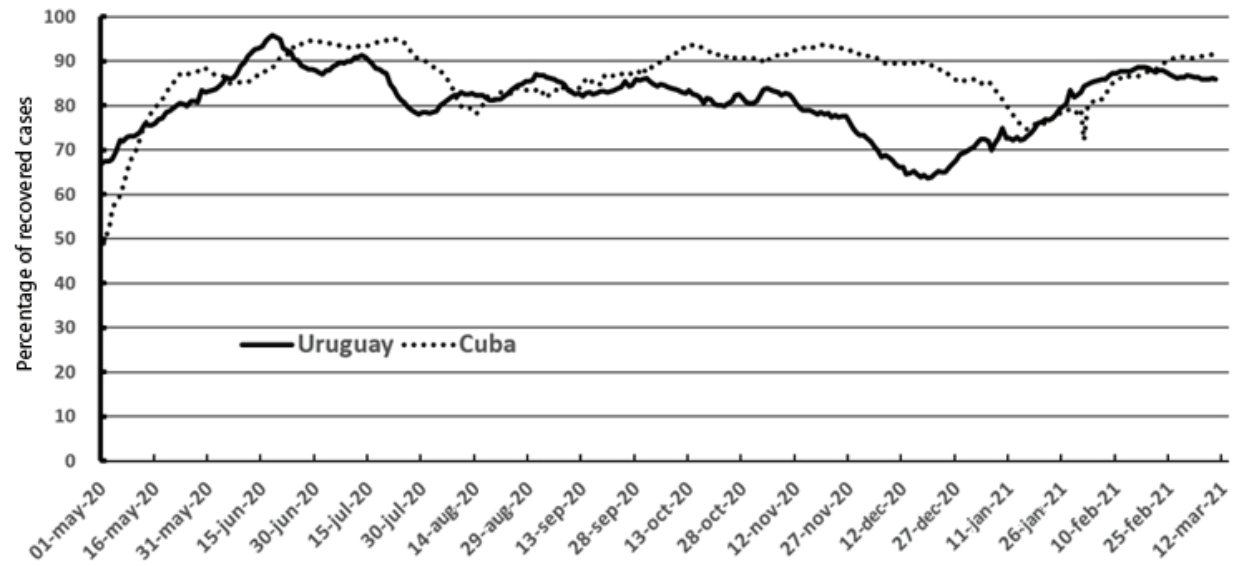

Figure 5: Crude COVID-19 mortality rates per million population, Cuba and Uruguay; May 1, 2020-March 10, 2021

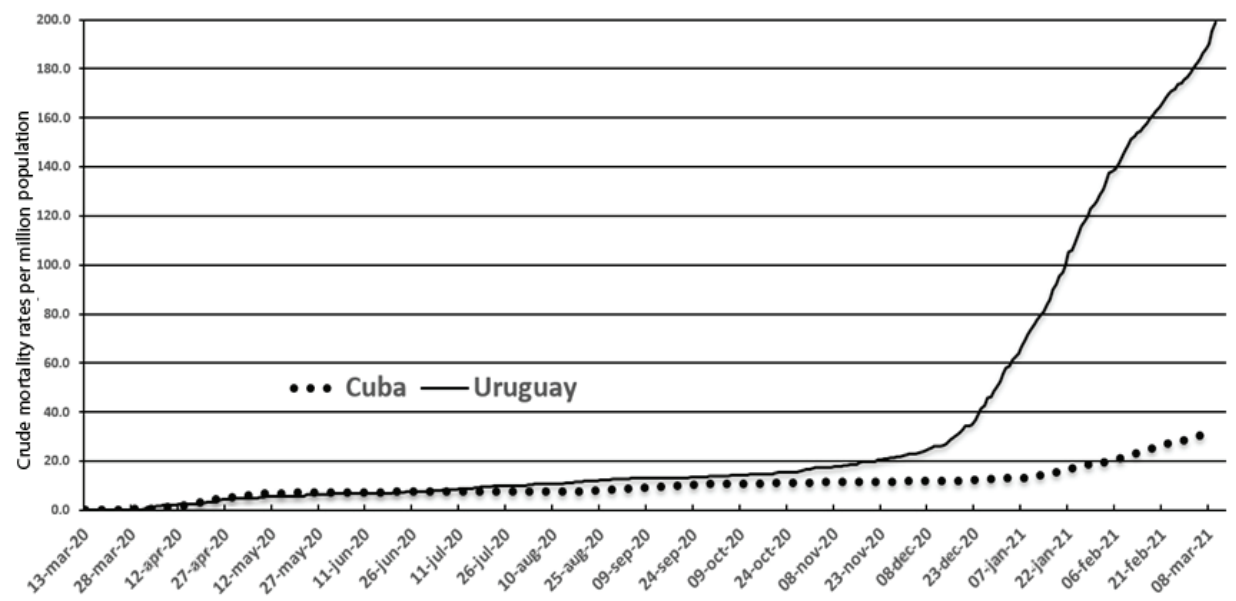

that is over six times higher, as is seen in the table. The latter country has a population 3 times smaller (3 461734 vs 11333483 population), which produces a mortality rate per million population more than 6 times higher in Uruguay (Table).

It should be noted, however, that in both countries most deaths correspond to persons who died 'with' COVID, and not strictly 'from' COVID in the sense that, for the most part, they were elderly patients who, at the time of death, suffered from important comorbidities such as chronic obstructive pulmonary disease (COPD), cardiovascular diseases, diabetes, chronic kidney disease, cancer and obesity, among others.

The average age of the deceased has been high and almost the same in the two countries: approximately 75 years. There have been no deaths in pediatric age groups. Except for 4 Uruguayan citizens and 1 Cuban, none of the remaining 1,044 deceased to date was under 35 years old.

The media's treatment of the epidemic In the context of the comparison between Cuba and Uruguay proposed by this study, the information that has been provided on the epidemic exhibits some unique features. For example, Cuba and Uruguay were the only countries in the region that welcomed an international cruise ship shortly after the start of the pandemic.

Table: COVID-19 morbidity and mortality in 16 Latin American countries; March 11, 2020-March 10, 2021

\begin{tabular}{|c|c|c|c|c|c|c|c|c|}
\hline Rank & Country & $\begin{array}{l}\text { Total } \\
\text { deaths }\end{array}$ & $\begin{array}{l}\text { Crude mortality } \\
\text { rate per million } \\
\text { population }\end{array}$ & $\begin{array}{l}\text { Relative risk } \\
\text { of dying from } \\
\text { COVID-19 }\left(\mathbf{R R}_{1}\right)^{*}\end{array}$ & $\begin{array}{l}\text { Total } \\
\text { cases }\end{array}$ & $\begin{array}{c}\text { Accumulated } \\
\text { incidence rate per } \\
\text { million population }\end{array}$ & $\begin{array}{l}\text { Relative risk of } \\
\text { becoming ill from } \\
\text { COVID-19 }\left(\mathrm{RR}_{2}\right)^{*}\end{array}$ & $\begin{array}{c}\text { Weighted } \\
\text { average of the two } \\
\text { relative rates (MWRR) }\end{array}$ \\
\hline 1 & Cuba & 357 & 31.5 & 1.0 & 58,379 & 5154.1 & 1.0 & 1.000 \\
\hline 2 & Uruguay & 678 & 195.2 & 6.2 & 66,484 & $19,139.1$ & 3.7 & 0.858 \\
\hline 3 & Guatemala & 6,522 & 364.0 & 11.6 & 180,393 & $10,069.1$ & 2.0 & 0.837 \\
\hline 4 & $\begin{array}{l}\text { Dominican } \\
\text { Republic }\end{array}$ & 3,198 & 294.8 & 9.4 & 244,168 & $22,508.3$ & 4.4 & 0.799 \\
\hline 5 & Honduras & 4,301 & 434.2 & 13.8 & 175,442 & $17,713.2$ & 3.4 & 0.768 \\
\hline 6 & Paraguay & 3,387 & 474.9 & 15.1 & 174,013 & $24,397.1$ & 4.7 & 0.715 \\
\hline 7 & Costa Rica & 2,848 & 559.1 & 17.7 & 207,832 & $40,798.5$ & 7.9 & 0.594 \\
\hline 8 & Ecuador & 16,105 & 912.8 & 29.0 & 296,841 & $16,824.8$ & 3.3 & 0.576 \\
\hline 9 & Bolivia & 11,884 & 1018.1 & 32.3 & 256,462 & $21,970.5$ & 4.3 & 0.505 \\
\hline 10 & Chile & 21,206 & 1109.3 & 35.2 & 867,949 & $45,403.8$ & 8.8 & 0.343 \\
\hline 11 & Mexico & 192,491 & 1493.0 & 47.4 & $2,144,486$ & $16,632.6$ & 3.2 & 0.339 \\
\hline 12 & Colombia & 60,773 & 1194.4 & 37.9 & $2,285,960$ & $44,925.9$ & 8.7 & 0.311 \\
\hline 13 & Argentina & 53,359 & 1180.6 & 37.5 & $2,169,694$ & $48,006.6$ & 9.3 & 0.300 \\
\hline 14 & Brazil & 270,656 & 1273.3 & 40.4 & $11,202,305$ & $52,702.0$ & 10.2 & 0.237 \\
\hline 15 & Peru & 48,163 & 1460.7 & 46.3 & $1,380,023$ & $41,854.6$ & 8.1 & 0.218 \\
\hline 16 & Panama & 5,957 & 1380.6 & 43.8 & 346,301 & $80,259.5$ & 15.6 & 0.046 \\
\hline
\end{tabular}

${ }^{*}$ Relative risk of dying from COVID-19 (rate ratio): COVID-19 mortality rate in the country / COVID-19 mortality rate in Cuba; ** Relative risk of becoming ill from COVID-19 (rate ratio): in-country COVID-19 incidence rate/ COVID-19 incidence rate in Cuba. Source: Table prepared based on data from: https://www.ourworldindata.org/coronavirus 
Amidst great anxiety provoked worldwide by the still little-studied threat, on March 13, 2020, the MS Braemar cruise ship, with numerous sick passengers, floated through the Caribbean with no country willing to receive it and host its passengers, as requested by the British government. Only Cuba assumed the enormous dangers posed by receiving travelers and facilitating their return by air to London.[28] BBC World News ignored the story. It is difficult to believe that, for an event of such extraordinary significance, the omission was the result of distraction. A similar gesture by the Uruguayan government a month later with the Australian cruise ship Greg Mortimer prompted high praise from the same service. [29]

As is well known, the 'virus' of distorted, tendentious or completely fabricated information-the so-called 'infodemic'-appeared across the world as soon as this health emergency began. Indeed, the novel coronavirus pandemic has been an opportunity to manufacture stories inspired by extra-scientific interests. In addition to promoting certain stereotypes, we see efforts to conceal those truths that would call them into question. That is to say, the dissemination of false information in news reports and social media, occasionally is accompanied by deliberate omission of facts.

Notable in this context is the repeated absence of Cuba when references are cited showing good management of the epidemic.

For an extended time, the media highlighted the situation of some countries, such as Uruguay, Costa Rica and Paraguay, that were considered the three countries 'winning' against COVID-19,[30] while omitting all mention of Cuba, a country that shared that privileged position in the COVID-19 epidemiology in the region. The politicization of discourse complements information bias. By way of illustration, take as an example the following text published by CNN in May: "The success of Paraguay, Costa Rica and Uruguay in the fight against the pandemic seems to contradict the generalized belief that dictatorships are more successful than democratic governments in the fight against these pandemics."[31] In some media outlets, even in late October, Uruguay and Paraguay are exalted, but Cuba is omitted, as if it did not exist and as if it were not experiencing the greatest success in handling the pandemic in the region. This led to the general opinion that: "with the exception of Uruguay and Paraguay, mortality from COVID-19 in Latin America is very high" or "except for Uruguay and Paraguay, Latin American countries have fared considerably worse than the European countries and the United States."[32]

Recently, on January 27, 2021, the Lowy Institute in Sydney released a report[33] that reflects very clearly the distortions to be found both in academic analyses and their impact in the media. The study places 100 countries, a list not including Cuba, along a ranking based on an index comprised of six indicators that involve (in a very confusing way) cases, deaths and tests performed. Despite the opaque methodology used to construct this index and the fact that a convincing explanation is not given for the exclusion of certain countries, thousands of journalistic and digital media worldwide (Google contains more than 300,000 entries with this information) reported the results as if it were a global 'barometer' that merited no objection. For example, Uruguay's media used it to proclaim that "Uruguay is the best-positioned country in the entire American continent"[34] or "Uruguay is the best in America."[35]

\section{DISCUSSION}

The results inspire both discussion and reflection. On the one hand, we have the favorable position shared by Cuba and Uruguay in the regional context. On the other hand, there is the similar development of the epidemic in the two countries during the first eight months, and the marked distancing of their indicators in the final period analyzed, although they continue to maintain certain parallels in their trends.

From the Latin American worldview, Cuba has maintained a leading position in its response to the pandemic, although, as in any other enclave on the planet, there is a risk that the epidemicwhich at one point seemed completely cornered-could fly out of control. This has occurred dramatically in some countries, such as Ireland, which accumulated in just one month as many cases as it had in the previous nine months, or in the Czech Republic where the crisis has been overcome again and again and yet shortly thereafter record-breaking figures emerge. In Latin America, the countries that seemed to be 'on the right track' (notably, Costa Rica and Paraguay) now exhibit indicators several dozen times more disadvantageous (Table).

In hindsight, the triumphant exaltations of the press suggest the need to maintain a more cautious profile. Framing certain achievements as if they were immutable can generate excesses of confidence that, in the end, can be counterproductive.

A full understanding of the dynamics of a pandemic like COVID-19 will not be achievable for some time. But an analysis of what happened over the first 12 months can establish some provisional explanations. Understanding the processes that lead to the currently evolving issues experienced both in Cuba and Uruguay, is as challenging as explaining their favorable evolutions in the first months of the pandemic.

The processes underlying the epidemic's production and reproduction are of different origins and interact in complex ways. Structural aspects like social organization and relative economic situations, applied policies, the health system and demographic structures interact with aspects that arise from ways of life and lifestyles deeply rooted in social and cultural dimensions, influenced in turn by categories such as social class, gender, age and ethnicity. Fully deciphering this latticework and its multiple combinations, which can produce different expressions of epidemics caused by the same virus, transcends the possibilities of this paper. Even knowing that more questions than answers may be raised, some of the aforementioned features and corresponding responses to the epidemic in each country are examined below, which may contribute to understanding the pandemic's evolution.

The demographics and human development indicators in Cuba and Uruguay reflect several similarities that, although they favor the countries' advantageous epidemiological situations in the region, are insufficient to explain this shared success all by themselves. On the other hand, the course of the epidemic exhibited different patterns. Consequently, we propose the following dimensions in this discussion: a) available resources and the health system, b) social and cultural support for the country's pandemic response.

Undoubtedly the strengths of the Cuban health system have been behind its achievements regarding the COVID-19 pandemic. 
Possessing a powerful and free-of-charge public National Health System, with universal access and coverage, Cuba has some 500 polyclinics throughout the nation, with 12,000 family doctorand-nurse offices in communities and nearly 500,000 workers in the health sector. There is one nurse for every 133 population (75 nurses per 10,000 population) and one doctor for every 116 population which means that the rate rises to 87 physicians per 10,000 population, the highest in the world. It also has a vast network of health institutions for secondary and tertiary care, and numerous centers for epidemiological surveillance articulated with primary care, as well as prestigious centers for public health, medical and biotechnological research. Additionally, it has managed to develop and implement flexible, advanced protocols for patient care in accordance with the best existing knowledge.[36-38]

The Cuban health system's ability to adapt to new challenges is also noteworthy. In the words of Dr Carissa Etienne, Director General of the Pan American Health Organization: "Cuba expanded the extremely strong health system that it already had, further expanded this network to include more health workers and medical students, incorporating digital tools to improve contactand case-tracing. They used a very well-established health system that now includes new elements from this pandemic."[39] Cuba has managed to articulate intersectoral action, essential to configure responses that are both agile and socially organized with an aim of developing activities to prevent infections and deaths. Cubans have seen, day by day, how all the ministries, information sources (with no private radio or TV channels in the country) and social actors have mobilized around a National Plan for Prevention and Control of SARS-CoV-2, for the defense and care of the population threatened by the virus.

Last century, a scholar noted "when we are facing a sudden disastrous event, such as a cyclone, an earthquake, or flooding, various features of the affected societies become apparent. The stress it causes puts social stability and cohesion to the test."[40] It is well known that the periodic hurricanes passing through the Caribbean, Mexico and the United States often leave a trail of deaths in their wake, which is nevertheless unfamiliar to Cubans. This is not a matter of luck: it represents defense capacities organized by the State, and, above all, actively supported by the population. The spread of a highly contagious virus is more insidious than the impact of a cyclone and represents a more lasting and complex challenge, but the social cohesion evident in the Cuban response has also been vital in the face of this health emergency.

Uruguay has a National Integrated Health System (SNIS). Its initiation in 2008 made it possible to overcome the system's fragmentation and optimize its financing, as well as guarantee practically universal comprehensive healthcare coverage. With 44 public and private providers, the financing and management of the SNIS is carried out by the State.[41] Its government agencies are supported by the social participation of workers and users. Three main axes supported the health reform. Two of themchanges to management and financing models-advanced and were consolidated throughout the first decade of the system; but the third-transformation of the healthcare model itself-has been slow, incomplete, and is not yet consolidated.

Many of the system's providers lack sufficiently developed work at the primary healthcare level and in the community context.
Although progress has been made in infrastructure, organization of work in this area has not been prioritized by institutions, inclusion of specialists in family and community medicine is insufficient, there is a deficit of nursing and mental health professionals, and remunerations are not attractive. There is also no functional career path at this (primary care) level; that is, no institutional or material progression is foreseen for these professionals. The hospitalcentric imprint that the SNIS tried to overcome still survives.

An event that occurred at the beginning of the epidemic in Uruguay clearly illustrates these problems: most primary care health services in the State Health Services Administration (ASSE) in Montevideo, Canelones and the country's other departments were closed in March and their personnel were redistributed to make them available for face-to-face or telephone consultations in other spaces. The reactions of the professionals involved, particularly those of the Uruguayan Society of Family and Community Medicine (SUMEFAC), supported by the Uruguayan Medical Union (SMU) and the Users' Movement, managed to reverse the situation and reestablish health teams within their communities.[42]

Additionally, primary care is not adequately prioritized in protocols designed to address the COVID-19 epidemic, especially regarding epidemiological surveillance and information systems. In this crucial area, the contrast between Uruguay and Cuba is noteworthy.

Uruguay maintains a centralized surveillance mechanism. For the COVID-19 epidemic, a tracing system was established whose capacity was quickly exceeded-even when it doubled in number-during the month of November, when the virus began to spread rapidly.[43]

It is not our intention to draw conclusions based on these realities, but the 'inability' (or exceeded capacity) of Uruguay's centralized epidemiological surveillance system should not be overlooked, nor its insufficient assignment of a leading role to primary care for monitoring the epidemic. Both deficiencies, absent in Cuba, could partially explain the lower levels of epidemic control in Uruguay.

Broadly speaking, it can be said that in Uruguay no mandatory restrictions on movement have been imposed, although measures-very strong at the beginning of the epidemic, more tenuous in recent months-have been established to reduce mobility linked to work, childcare and recreation (closure of schools, encouragement to telework, suspension of public shows, reduced capacity in interdepartmental buses, and prohibitions related to gatherings, among others). Mandatory masking was established in some settings as the epidemic advanced in 2020.

In general terms, the limitations imposed in Cuba have been similar, although flexibly adjusted depending on the epidemic's geography. Perhaps the most important distinguishing measure lies in Cuba's hospitalization of all infected persons (including asymptomatic patients) and the isolation of both the contacts of diagnosed cases and of suspected cases detected by the primary care system. Initially, there were strict limitations on travelers' entry into the country, which were relaxed in September. However, due to outbreaks linked to incoming travelers, these limitations were re-established at the end of the year. This evolution reflects the delicate balance between measures that favor economic recovery and those that hinder the pathogen's spread. 
The participation of scientific and academic communities in both countries is worth highlighting, as is the early establishment of [interdisciplinary] collaboration.

It is plausible that the favorable mortality figures on record can be attributed to high quality of both health systems and services, as well as to the application of COVID-specific care protocols. Additionally, the very low case fatality rate in both countries, 12 months after the first cases $(0.61 \%$ in Cuba and $1.02 \%$ in Uruguay), supports this hypothesis.

Domestic manufacture of COVID-19 diagnostic technology enabled adequate coverage of this key aspect in the pandemic, independent of the international market. Diagnostic testing capacities increased progressively throughout 2020, without interruption in Cuba and with only a few intermittent interruptions in Uruguay, guaranteeing availability of the number of tests needed for each stage of the epidemic. The non-proportional increase in the number of tests with respect to the accelerated increase in cases during DecemberMarch has translated into increased positivity (Fig. 4) and leads us to wonder if need has exceeded capacity and if this constitutes a critical point for controlling the epidemic in Uruguay at its current stage.

One result of this scientific-academic collaboration in Uruguay was the formation in April 2020 of the Honorary Scientific Advisory Group $(\mathrm{GACH})$, a group of academics, teachers and researchers established as a consultative body at the request of the national government, to serve as interlocutors for decision-making and analysis of pandemic management measures. The $\mathrm{GACH}$ has been functioning since its creation.

The setbacks observed in the two countries require more in-depth examination, which goes beyond the scope of this study. Not having been able examine these setbacks constitutes a limitation of this paper, but we identified areas that should complement such an analysis in the future.

For example, all countries have experienced community circulation of SARS-CoV-2. However, an examination of the degree to which community organization has affected spread is still pending, using methodological approaches that consider each locality's unique characteristics. The participation of the health system's communitybased entities and of communities themselves in the management of the epidemic been different in Cuba and Uruguay. It makes sense to think that high degree of social involvement played a role in the favorable evolution of the epidemic in Cuba, although this is conjecture at this point and requires more intense scrutiny.
In both countries, a greater role for the social sciences could be of assistance,[44] an idea called for by, among others, by the Spanish Political Sciences and Administration Association (AECPA). Despite the difficulties, the exigencies posed by COVID-19 should prompt all countries in the region, without exception, to go beyond biomedical sciences in our response, as was recently recommended by $\mathrm{WHO}$. [45] The crisis demands the attention of public health professionals and epidemiologists, complemented by the work of historians, virologists, clinicians, philosophers, geographers, theologians and behavioral scientists, among others, to understand and address the problem.

Actions must appeal to the wisdom of community leaders and not be reduced to the sometimes chimerical demand to fulfill norms of behavior that ignore singularities unique to each locality, nor should health systems be made to shoulder the exclusive responsibility for prevention. An examination of the future of the epidemic in Latin America in general, and in Uruguay and Cuba in particular, seems to advocate for such an approach.

Two fundamental lessons follow from this study. The first and most important is that given what we know of SARS-CoV-2 it is not possible to happily 'declare victory,' since what seems a very favorable situation can be abruptly reversed. The second is that the most fruitful comparative analyses between countries or regions must consider sociodemographic and political factors (especially population size) influencing the ways in which the epidemic unfolds, as well as be cautioned against information biases induced by the media.

Various issues affecting multiple territories in Latin America, including of course both Cuba and Uruguay, merit continued attention. This paper offers a modest contribution in this direction, but the pandemic has opened numerous avenues for study today and in the future.[46] Examples include: the impact of the contempt that some statesmen hold for science, individuals who routinely contradict and undermine experts leading the response to COVID-19; the extent to which inequality has catalyzed tragedy; and the impact the pandemic has had in the deepening of inequalities by race, gender and class.

Finally, we conclude that any characterization of the situation is condemned to be ephemeral due to the ever-changing nature of the epidemic and its viral mutations; however, this analysis allowed us to identify favorable sociodemographic characteristics in both nations, as well as those of their health systems, and to provide possible explanations for each country's relatively favorable outcomes.

\section{REFERENCES}

1. Ministerio de Salud Pública (Cuba). Nueva versión del protocolo de actuación nacional para la COVID-19. La Habana: MINSAP; 2020 [cited 2021 Feb 28]. Available at: http://www.sld.cu/ anuncio/2020/08/13/ministerio-de-salud-publi ca-nueva-version-del-protocolo-de-actuacion -nacional-par

2. World Health Organization. COVID-19 clinical management: living guidance. Geneva: WHO; 2021 [cited 2021 March 01]. Available at: https:// www.who.int/publications/i/item/who-2019-ncov -clinical-2021-1

3. Alemán A, Pintos J, Ponzo J, Salgado M, Botti H; Grupo Uruguayo interdisciplinario de Análisis de Datos de COVID-19. (Guiad-COVID-19). Nota 4: evidencia del impacto sobre la evolución de la epidemia de algunas medidas de control.
Reportes Téc; 2020 [cited 2021 Feb 28]. Available at: https://www.colibri.udelar.edu.uy/jspui/ bitstream/20.500.12008/26768/1/nota_4_impac to_medidas_control_guiad-covid19.pdf

4. Spinney I. El jinete pálido. 1918: la epidemia que cambió el mundo. Barcelona: Crítica; 2018[cited 2021 Feb 28]. Available at: https://static0planet adelibroscommx.cdnstatics.com/libros_conteni do extra/38/37150 el jinete palido.pdf

5. Douglas island news. Do's and dont's for influenza prevention. Alaska: Douglas city;1918 [cited 2021 Feb 28];52. Available at: https://www.news papers.com/clip/47051883/douglas-island -news/

6. Loewy MA. COVID-19: todavía estamos lejos de que la pandemia se vuelva endemia. Medscape Noticias Médicas. 13 de noviembre de 2020 [cit- ed 2021 Feb 28]. Available at: http://www.espa nol.medscape.com/verarticulo/5906179

7. Ellyatt H. Coronavirus likely to become as "endemic" as the flu and a vaccine might not be able to stop it, top uk scientist says. EE. UU.: CNBC. 20 0ctubre 2020 [cited 2021 Feb 28]. Available at: https://www .cnbc.com/2020/10/20/COVID-19-likely-to-become -as-endemic-as-flu.html_-

8. Endcoronavirus. A multi-disciplinary effort to eliminate COVID-19. New England Complex Systems Institute: Endcoronavirus.org; 2020 [cited 2021 March 01]. Available at: https://www endcoronavirus.org/

9. Johns Hopkins Coronavirus Resource Center Baltimore, Maryland: University Johns Hopkins; 2020 [cited 2021 March 01]. Available at: https:// coronavirus.jhu.edu/map.html 
10. Global Epidemics. Pandemics explained unlocking evidence for better decision making. [cited 2021 March 01]. Available at: https://www globalepidemics.org/

11. World Health Organization. Coronavirus disease situation dashboard. Who coronavirus disease (COVID-19) dashboard. Geneva: WHO; 2020 [cited 2020 Oct 19];352. Available at: https:// www.newspapers.com/clip/47051883/douglas -island-news/

12. Ramonet I. La pandemia y el sistema-mundo. Le Monde Diplomatique en español. 2020 [cited 2021 Feb 28]. Available at: https://mondiplo.com/ la-pandemia-y-el-sistema-mundo

13. Muñoz R. COVID-19 en América Latina: ¿qué revelan las cifras? ¿y qué no? Deutsche Welle. 2020 [cited 2021 Feb 28]. Available at: https:// www.dw.com/es/COVID-19-en-am\%c3\%a9rica -latina-qu\%c3\%a9-revelan-las-cifras-y-qu\%c3 \%a9-no/a-54257083

14. CNN en español. Nuevas cifras oficiales de COVID-19 en Nicaragua distan de reporte del Observatorio Ciudadano sobre coronavirus. Nicaragua: Ministerio del Poder Ciudadano para la Salud;2020 [cited 2021 Feb28]. Available at: https:// wtop.com/news/2020/06/nuevas-cifras-oficiales -de-covid-19-en-nicaragua-distan-de-reporte -del-observatorio-ciudadano-sobre-coronavirus/

15. Hurtado J. Nicaragua y el Covid-19: entre la falta de información y un gobierno que anima a aglomerarse. América latina: Representación de France 24; 14 septiembre 2020 [cited 2021 Feb 28]. Available at: https://www.france24.com/ es/20200914-nicaragua-seis-meses-pandemia -covid-19-falta-informacion

16. Porcecansky R. Éxitos y fracasos en la gestión regional de la pandemia. Uruguay: El País. Digital. 29 de junio de 2020 [cited 2021 Feb 28] Available at: https://www.elpais.com.uy/econo mia-y-mercado/exitos-fracasos-gestion-regional -pandemia.htm

17. Arévalo K. Alto subregistro y tendencia atípica en datos de COVID-19 en los primeros seis meses de la pandemia en el salvador. Noticias de EI Salvador: elsalvador.com. Digital. 26 de septiembre de 2020 [cited 2021 Feb 28]. Available at: https:// www.elsalvador.com/noticias/nacional/subregis tro-cifras-atipicas-de-COVID-19-en-seis-meses -pandemia/757537/2020/

18. Avelar L. Ministerio de salud ordenó ocultar información sobre pruebas COVID-19. Revista Factum digital. 8 de octubre de 2020 [cited 2021 Feb 28]. Available at: https://www.revistafactum.com/ minsal-oculta-info-covid/

19. Harvard Global Health Institute and Edmond J. Safra Center for Ethics. Key metrics for Covid suppression, a framework for policy makers and the public. EE.UU.: Harvard Global Health Institute; 2020 [cited 2020 Dec 27]. Available at: https://glo balepidemics.org/wp-content/uploads/2020/09 /key metrics and indicators v5-1.pdf

20. Organización Mundial de la Salud. Criterios de salud pública para ajustar las medidas de salud pública y sociales en el contexto de la covid-19. Anexo de: consideraciones para aplicar y ajustar medidas de salud pública y sociales en el contexto de la Covid-19. Geneva: WHO; 2020 [cited 2020 Dec 28]. Available at: https://apps .who.int/iris/bitstream/handle/10665/336990/ who-2019-ncov-adjusting_ph_measures -2020.2-spa.pdf

21. Sistema Nacional de Emergencias. Información actualizada sobre coronavirus COVID-19 en Uruguay. Uruguay: Presidencia del Gobierno; 7 marzo de 2021 [cited 2021 Feb 28]. Available at: https://www.presidencia.gub.uy//comunicacion/ comunicacionnoticias/reporte-covid-7-marzo

22. Grupo Uruguayo interdisciplinario de Análisis de Datos de COVID-19. Guiad-COVID-19. Uruguay: Grupo; 2020 [cited 2021 Jan 11]. Available at: https://guiad-covid.github.io/

23. Ministerio de Salud Pública. Coronavirus en Cuba. La Habana Ministerio de Salud Pública de
Cuba; 2021 [cited 2021 March 02]. Available at: https://salud.msp.gob.cu/parte-de-cierre-del-dia -1-de-marzo-a-las-12-de-la-nochel

24. Programa de Naciones Unidas para el Desarrollo. Informe sobre desarrollo humano 2020. Panorama general. La próxima frontera el desarrollo humano y el antropoceno. Nueva York: PNUD; 2020. Available at: http://hdr.undp.org/sites/ default/files/hdr_2020_overview_spanish.pdf

25. Monreal P. Desigualdad global: ¿dónde se ubica Cuba? [blog de Pedro Monreal sobre Cuba]. Cuba: El Estado como tal.com. 29 de abril de 2017 [cited 2021 Feb 28]. Available at: https:// elestadocomotal.com/2017/04/29/desigualdad -global-como-se-ubica-cuba/

26. Pearce N, Vandenbroucke JP, Vanderweele TJ, Greenland S. Accurate statistics on COVID-19 are essential for policy guidance and decisions. Am J Public Health. 2020 [cited 2021 Feb 28];110(7):949-51. Available at: https:// ajph.aphapublications.org/doi/full/10.2105/ ajph.2020.305708

27. Dowdy D, D'Souza G. COVID-19 testing: understanding the "percent positive". Questions and answers. [Johns Hopkins Bloomberg School of Public Health. Baltimore, EE. UU.: Universidad Johns Hopkins; 2020 [cited 2021 March 01]. Available at: https://www.jhsph.edu/COVID-19/ articles/COVID-19-testing-understanding-the -percent-positive.html

28. Ministerio de Relaciones Exteriores de Cuba. Redacción Digital. La Habana: MINREX; 2020. Cuba recibirá y brindará atención a viajeros con coronavirus del crucero británico ms braemar. Granma.cu [Internet]. Digital. 16 de marzo de 2020 [cited 2021 Feb 28]. Available at: http://www .granma.cu/Cuba-COVID-19/2020-03-16/minrex -Cuba-recibira-y-brindara-a-atencion-a-viajeros -con-coronavirus-del-crucero-britanico-ms -braemar

29. BBC News Mundo. Redacción. La emocionante evacuación del crucero australiano con COVID-19 en Uruguay. Uruguay: Representación BBC News Mundo. Digital. 27 de abril de 2020 [cited 2021 Feb 28]. Available at: https://www .bbc.com/mundo/noticias-52426722

30. Oppenheimer A. Los 3 países de la región que le están ganando al COVID-19. Miamia: El Nuevo Herald. Digital. 27 de mayo de 2020 [cited 2021 Feb 28]. Available at: https://www.elnuevoherald com/opinion-es/opin-col-blogs/andres-oppen heimer-es/article243023531.html

31. Montaner CA. Opinión | coronavirus: "Uruguay, el oasis de la pandemia en américa del sur" [Internet]. Uruguay: Representación CNN en español; 2020 [cited 2021 Feb 28]. Available at: https:// cnnespanol.cnn.com/2020/05/22/opinion-coro navirus-Uruguay-el-oasis-de-la-pandemia-en -america-del-sur/

32. Berniel L, de la Mata D, Cabral G. Demografía y pandemia: qué revelan las muertes por COVID-19 en América Latina [blog]. Caf. Banco de Desarrollo de América Latina. 2020 [cited 2021 Feb 28]. Available at: https://www.caf.com/ es/conocimiento/visiones/2020/10/demografia-y -pandemia/

33. Leng A, Lemahieu $\mathrm{H}$, Smith $\mathrm{B}$. What impact has geography, political systems, population size, and economic development had on COVID-19 outcomes around the world? Covid Performance Index. Sydney: Lowy Institute; 2021 [cited 2021 Feb 28]. Available at: https://interactives.lowyin stitute.org/features/covid-performance/

34. El País. Instituto Lowy: lista global sobre el manejo de la pandemia; ¿en qué lugar quedó Uruguay? Uruguay: El País. Digital 28 de enero de 2021. Available at: https://www.elpais.com .uy/informacion/salud/instituto-lowy-lista-global -manejo-pandemia-lugar-quedo-uruguay.htm

35. Instituto Lowy de Sydney. Índice lowy de gestión de pandemia: Uruguay 120 entre 99 países y es mejor de América. Uruguay: Montevideo Portal; 2021 [cited 2021 Feb 28]. Available at: Silva LC.
Cuba y las enseñanzas que dejan seis meses de enfrentamiento a la COVID-19. Escenarios pospandemia: reflexionando sobre casos del sur global y otros territorios. Florianópolis: Editora Cultura Académica; 2020.

36. Pérez L. Ampliación y reorganización de los servicios de salud y recursos humanos durante la pandemia. Andar la Salud. Boletín OPS en Cuba. 2020;24(2):17-9.

37. Del Pino T. Intervienen autoridades de la salud pública cubana en sesiones informativas de OPS y OMS. Andar la Salud. Bol OPS en Cuba. 2020;24(2):5-8.

38. Organización Panamericana de la Salud En Cuba. Gestión asistencial y de ciencia. Andar la Salud. Bol OPS en Cuba. 2020;24(2):8-9.

39. Porter D. Health, civilization, and the state: a history of public health from ancient to modern times. London, New York: Routledge; 1999.

40. Sistema Nacional Integrado de Salud. Normativa referente a su creación, funcionamiento y financiación. Ley 18.211. Uruguay: Gobierno de Uruguay. 2007 [cited 2016 Aug 18]. Available at: https://legislativo.parlamento.gub.uy/temporales/ leytemp5504426.htm

41. La Diaria. Médicos de familia y comunitarios solicitan la reapertura de 48 policlínicas de ASSE en el área metropolitana. Uruguay: La Diaria. Digital. 16 de abril de 2020 [cited 2021 March 02]. Available at: https://ladiaria.com.uy/politica/ articulo/2020/4/medicos-de-familia-y-comunitar ios-solicitan-la-reapertura-de-48-policlinicas-de -asse-en-el-area-metropolitana/

42. Radio Sarandí 690 AM. Rafael Radi: si llegamos a la zona de 100 casos por día se empieza a complicar el partido. Montevideo; Informativo Sarandí; 2020 [cited 2021 Feb 28]. Available at: https://www.sarandi690.com.uy/2020/11/06/ rafael-radi-si-llegamos-a-la-zona-de-100-casos -por-dia-se-empieza-a-complicar-el-partido/

43. Asociación Española de Ciencias Políticas y de la Administración, Asociación de Antropología del Estado Español, Asociación Española de Geografía, Asociación Española de Investigación de la Comunicación, Federación Española de Sociología, Sociedad Española de Pedagogía. Las ciencias sociales y la gestión e investigación de la COVID-19. Comunicado ciencias sociales COVID-19.

44. Kluge HHP. Statement - rising COVID-19 fatigue and a pan-regional response. Geneva: WHO, Regional Office for Europe. 2020 [cited 2021 Feb 28]. Available at: https://www.euro.who .int/en/media-centre/sections/statements/2020/ statement-rising-COVID-19-fatigue-and-a-pan -regional-response

45. Freedland J. The magnifying glass: how covid revealed the truth about our world. London The Guardian. 2020 [cited 2021 Feb 28]. Available at: http://www.theguardian.com/ world/2020/dec/11/covid-upturned-planet -freedland

\section{THE AUTHORS}

Luis Carlos Silva-Ayçaguer (Corresponding author: Icsilvaa@yahoo.com). National School of Public Health, Havana, Cuba. https://orcid .org/0000-0002-0734-0054

Jacqueline Ponzo-Gómez, University of the Republic, Faculty of Medicine, Montevido, Uruguay. https://orcid.org/0000-0002-8329-7430

\section{Author contributions}

Both authors contributed equally to the design and development of the entire article.

https://doi.org/10.37757/MR2021.V23.N3.13 